\title{
Pengaruh Kompensasi dan Lingkungan Kerja terhadap Semangat Kerja Pegawai di Sekretariat Komisi Pemilihan Umum Kota Tebingtinggi
}

\author{
Rodi Syafrizal \\ Sekolah Tinggi Ilmu Ekonomi Bina Karya Tebing Tinggi \\ rodisyafrizal@gmail.com
}

\begin{abstract}
Abstrak Penelitian ini dilakukan bertujuan untuk mengetahui bagaimana pengaruh dari Kompensasi dan Lingkungan Kerja secara bersamassama terhadap Semangat Kerja Pegawai di Kantor Sekretariat Komisi Pemilihan Umum Kota Tebing Tinggi.Hasil penelitian ini menunjukkan berdasarkan analisis data dan pembahasan hasil penelitian, peneliti menarik kesimpulan bahwa Variabel Kompensasi (X1) memiliki pengaruh yang negtif dan tidak signifikan terhadap Variabel Semangat Kerja (Y). sedangkan Variabel Lingkungan Kerja (X2) berpengaruh positif dan signifikan terhadap Variabel Semangat Kerja (Y). Namun secara bersama-sama (simultan) Variabel Kompensasi (X1), dan Variabel Lingkungan Kerja (X2) berpengaruh positif signifikan dan terhadap Variabel Semangat Kerja (Y). Dan berdasarkan nilai koefisien determinasinya menunjukkan jika Variabel Kompensasi (X1) dan Variabel Lingkungan Kerja (X2) dapat menjelaskan Variabel Semangat Kerja (Y) sebesar 28,0\%.

Kata Kunci Kompensasi, Lingkungan Kerja dan Semangat Kerja
\end{abstract}

\section{PENDAHULUAN}

Komisi Pemilihan Umum (KPU) adalah lembaga negara yang menyelenggarakan pemilihan umum di Indonesia. Pemilihan umum (pemilu) di Indonesia pada awalnya ditujukan untuk memilih anggota lembaga perwakilan, yaitu DPR, DPRD Provinsi, dan DPRD Kabupaten/Kota. Setelah amendemen keempat UUD 1945 pada 2002, pemilihan presiden dan wakil presiden (pilpres), yang semula dilakukan oleh MPR, disepakati untuk dilakukan langsung oleh rakyat dan dari rakyat sehingga pilpres pun dimasukkan ke dalam rangkaian pemilu. Pilpres sebagai bagian dari pemilu diadakan pertama kali pada Pemilu 2004. Pada 2007, berdasarkan Undang-Undang Nomor 22 Tahun 2007, pemilihan kepala daerah dan wakil kepala daerah (pilkada) juga dimasukkan sebagai bagian dari rezim pemilu. Pada umumnya, istilah "pemilu" lebih sering merujuk kepada pemilihan anggota legislatif dan presiden yang diadakan setiap 5 tahun sekali. Pemilu harus dilakukan secara berkala, karena memiliki fungsi sebagai sarana pengawasan bagi rakyat terhadap wakilnya.

KPU mempunyai tugas kewenangan sebagai berikut: (1) Merencanakan dan mempersiapkan pelaksanaan Pemilihan Umum; (2) Menerima, meneliti dan menetapkan Partai-partai Politik yang berhak sebagai peserta Pemilihan Umum; (3) Membentuk Panitia Pemilihan Indonesia yang selanjutnya disebut PPI dan mengkoordinasikan kegiatan Pemilihan Umum mulai dari tingkat pusat sampai di Tempat Pemungutan Suara yang selanjutnya disebut TPS; (4) Menetapkan jumlah kursi anggota DPR, DPRD I dan DPRD II untuk setiap daerah pemilihan; (5) Menetapkan keseluruhan hasil Pemilihan 
Umum di semua daerah pemilihan untuk DPR, DPRD I dan DPRD II; (6) Mengumpulkan dan mensistemasikan bahan-bahan serta data hasil Pemilihan Umum; (7) Memimpin tahapan kegiatan Pemilihan Umum.

Sebagai anggota KPU tentu memiliki tugas-tugas serta tanggung jawab yang besar dalam mendukung lancarnya kegiatan pemilihan umum yang dilakukan dan tentunya menyita energi dan waktu yang loyal demi kelancaran kegiatan. Mulai dari perencanaan hingga penyelengaraan. Oleh karena itu perlunya memperhatikan kompensasi dan lingkungan kerja anggota KPU demi mendorong produktifitas kinerja agar meningkat. Kompensasi yang berupa upah dan gaji yang memadai dan lingkungan kerja yang baik, akan memberikan kepuasan bagi anggota, sehingga mereka akan lebih bersemangat dalam bekerja. Mengingat pentingnya pemberian kesejahteraan bagi pegawai untuk kelangsungan hidup lembaga atau organisasi.

\section{LANDASAN TEORI}

\section{Kompensasi}

Menurut Hasibuan (2017:119) Kompensasi adalah semua pendapatan yang berbentuk uang, barang langsung atau tidak langsung yang diterima karyawan sebagai immbalan atas jasa yang diberikan kepada perusahaan. Pembentukan sistem kompensasi yang efektif merupakan bagian penting dari manajemen sumber daya manusia karena membantu menarik dan mempertahankan pekerjaan-pekerjaan yang berbakat. Selain itu sistem kompensasi perusahaan memiliki dampak terhadap kinerja strategis.

Sedangkan Menururt Wibowo (2016:271) Kompensasi merupakan jumlah paket yang ditawarkan organisasi kepada pekerja sebagai imbalan atas penggunaan tenaga kerjanya. Penjelasan dari kompensasi berupa uang adalah karyawan dibayar dengan sejumlah uang, sedangkan kompensasi berupa barang adalah kompensasiyang dibayarkan dengan barang kepada karyawannya. Nawawi berpendapat bahwa (2011:314). Kompensasi adalah penghargaan/ganjaran pada para pekerja yang telah memberikan kontribusi dalam mewujudkan tujuannya, melalui kegiatan yang disebut bekerja.

Dari uraian diatas, maka dapat disimpulkan bahwa kompensasi adalah imbal jasa yang diberikan organisasi kepada karyawannya karena telah melakukan kewajiban dengan memenuhi segala tugasnya.Kompensasi dapat berupa finansial maupun nonfinansial.

\section{Indikator Kompensasi}

Menurut Veithzal Rivai (2011:357) indikator Kompensasi finansial langsung, yang terdiri dari :

a. Gaji

Gaji adalah balas jasa dalam bentuk uang yang diterima karyawan sebagai konsekuensi dari kedudukannya sebagai seorang karyawan yang memberikan sumbangan tenaga dan pikiran dalam mencapai tujuan perusahaan atau dapat juga dikatakan sebagai bayaran tetap yang diterima seseorang dari keanggotaannya dalam sebuah perusahaan.

b. Bonus

Bonus adalah pembayaran sekaligus yang diberikan karena memenuhi sasaran kinerja atau uang yang dibayar sebagai balas jasa atas hasil pekerjaan yang telah dilaksanakan apabila melebihi target. Bonus juga merupakan kompensasi tambahan yang diberikan kepada seorang karyawan yag nilainya di atas gaji normalnya. Bonus 
juga bisa digunakan sebagai penghargaan terhadap pencapaian tujuan-tujuan spesifik yang ditetapkan oleh perusahaan, atau untuk dedikasinya kepada perusahaan.

c. Insentif

Insentif merupakan imbalan langsung yang dibayarkan kepada karyawan karena kinerjanya melebihi standar yang ditentukan. Insentif merupakan bentuk lain dari upah langsung di luar upah dan gaji yang merupakan kompensasi tetap, yang biasa disebut kompensasi berdasarkan kinerja (pay for performanceplan). Insentif adalah variabel penghargaan yang diberikan kepada individu dalam suatu kelompok, yang diketahui berdasarkan perbedaan dalam mencapai hasil kerja.Ini di rancang untuk memberikan motivasi karyawan berusaha meningkatkan produktivitas kerjanya

d. Kompensasi tidak langsung (fringebenefit)

Kompensasi tidak langsung (Fringebenefit) merupakan kompensasi tambahan yang diberikan berdasarkan kebijakan perusahaan terhadap semua karyawan sebagai upaya meningkatkan kesejahteraan para karyawan. Contohnya berupa fasilitas-fasilitas, seperti: asuransi-asuransi, tunjangan tunjangan, uang pensiun, dan lain-lain. Dengan kompensasi organisasi bisa memperoleh/ menciptakan, memelihara, dan mempertahankan produktivitas. Tanpa kompensasi yang memadai karyawan yang ada sekarang cenderung untuk keluar dari organisasi, tingkat absensi yang tinggi atau kedisiplinan yang rendah dan keluhan-keluhan lainnya yang bisa timbul.

\section{Lingkungan Kerja}

Menurut (Nitisemito dalam Nuraini 2013:97) linkungan kerja adalah segala sesuatu yang ada disekitar karyawan dan dapat mempengaruhi dalam menjalankan tugas yang diembankan kepadanya misalnya dengan adanya air conditioner (AC), penerangan yang memadai dan sebagainya. Lingkungan kerja merupakan salah satu faktor eksternal yang sangat berpengaruh dalam menunjang hasil kerja yang maksimal dalam setiap pekerjaan. Apabila lingkungan kerja kurang kondusif maka akan menyebabkan kinerja tenaga kerja yang akan menurun ini disebabkan kurangnya motivasi kerja yang muncul dari dalam diri tenaga kerja untuk bekerja dengan baik.

Lingkungan kerja merupakan bagian yang tidak dapat dipisahkan dan jenis dan lokasi pekerjaan dimana individu karyawan berada dan beraktivitas. Produktifitas karyawan dari pekerjaan bergantung pada tempat dan lingkungan tempat individu karyawan bekerja. Oleh karenanya, lingkungan kerja perlu mendapat perhatian yang sangat serius dan utama karena merupakan rumah kedua setelah tempat tinggal.

\section{Indikator Lingkungan Kerja}

a. Lingkungan Kerja Fisik

Lingkungan kerja fisik adalah semua keadaan berbentuk fisik yang terdapat disekitar tempat kerja dan dapat mempengaruhi karyawan. Siagian (2014:59) mengemukakan bahwa dimensi lingkungan kerja fisik terdiri dari beberapa indikator yaitu:

1) Bangunan tempat kerja

Bangunan tempat kerja di samping menarik untuk dipandang juga dibangun dengan pertimbangan keselamatan kerja, agar karyawan merasa nyaman dan aman dalam melakukan pekerjaannya.

2) Peralatan kerja yang memadai

Peralatan yang memadai sangat dibutuhkan karyawan karena akan mendukung karyawan dalam menyelesaikan tugas yang di embannya di dalam perusahaan. 
3) Fasilitas

Fasilitas perusahaan sangat dibutuhkan oleh karyawan sebagai pendukung dalam menyelasikan pekerjaan yang ada di perusahaan. Selain itu ada hal yang perlu di perhatikan oleh perusahaan yakni tentang cara memanusiakan karyawannya, seperti tersedianya fasilitas untuk karyawan beristirahat setelah lelah bekerja dan juga tersedianya tempat ibadah.

4) Tersedianya sarana angkutan

Tersedianya sarana angkutan akan mendukung para karyawan untuk sampai di tempat kerja dengan tepat waktu, baik yang diperuntukkan karyawan maupun angkutan umum yang nyaman, murah dan mudah di peroleh.

b. Lingkungan Kerja Non Fisik

Lingkungan kerja non fisik adalah terciptanya hubungan kerja yang harmonis antara karyawan dan atasan. Siagian (2014:61) mengemukakan bahwa dimensi lingkungan kerja non fisik terdiri dari beberapa indikator yaitu :

1) Hubungan rekan kerja setingkat Indikator hubungan dengan rekan kerja yaitu hubungan dengan rekan kerja yang harmonis dan tanpa saling intrik di antara sesama rekan sekerja. Salah satu faktor yang dapat mempengaruhi karyawan tetap tinggal dalam satu organisasi adalah adanya hubungan yang harmonis dan kekeluargaan.

2) Hubungan atasan dengan karyawan

Hubungan atasan dengan bawahan atau karyawannya harus di jaga dengan baik dan harus saling menghargai antara atasan dengan bawahan, dengan saling menghargai maka akan menimbulkan rasa hormat diantara individu masingmasing.

3) Kerjasama antar karyawan

Kerjasama antara karyawan harus dijaga dengan baik, karena akan mempengaruhi pekerjaan yang mereka lakukan. Jika kerjasama antara karyawan dapat terjalin dengan baik maka karyawan dapat menyelesaikan pekerjaan mereka secara efektif dan efisien.

\section{Semangat Kerja}

Semangat kerja menurut Hasibuan (2009:94) adalah "keinginan dan kesungguhan seseorang mengerjakan pekerjaannya dengan baik serta berdisiplin untuk mencapai prestasi kerja yang maksimal".. Apabila tenaga kerja bergairah dalam bekerja, dikatakan tenaga kerja memiliki moral yang tinggi. Sebaliknya apabila tenaga kerja tidak bergairah atau malas-malasan dalam bekerja, dikatakan tenaga kerja yang bersangkutan memiliki derajat moral yang rendah. Moral kerja yang rendah dapat menimbulkan pemogokan, sering mangkir, kepura-puraan, dan berbagai aksi lainnya. Jadi apabila mampu meningkatkan semangat kerja pegawai maka perusahaan akan memperoleh banyak keuntungan, pekerjaan akan lebih cepat diselesaikan, kerusakan akan dikurangi, tingkat absensi dan keterlambatan akan dapat diperkecil, kemungkinan perpindahan karyawan akan dapat dikurangi dan sebagainya. Dengan semangat kerja tersebut, maka pekerjaan akan lebih cepat diselesaikan, absensi dapat diperkecil dan kemungkinan perpindahan pegawai dapat diperkecil seminimal mungkin dan sebagainya. Adanya semangat kerja yang tinggi maka karyawan diharapkan akan mencapai tingkat produktivitas yang lebih baik, dan pada akhirnya menunjang terwujudnya tujuan dari perusahaan. 


\section{Indikator Semangat Kerja}

Berikut adalah beberapa indicator semangat kerja yang dikemukakan oleh Alex S. Nitisemito ( $2010: 427$ ), diantaranya adalah sebagai berikut

a. Naiknya produktivitas karyawan

Karyawan yang semangat kerjanya tinggi cenderung melaksanakan tugastugas sesuai waktu, tidak menunda pekerjaan dengan sengaja, serta mempercepat pekerjaan dan sebagainya.oleh karena itu harus dibuat standar kerja untuk mengetahui apakah produktivitas karaywan yang tinggi apa tidak. Dimensi naiknya produktivitas karyawan diukur dengan menggunakan tiga indikator yaitu

1) Professionalisme dalam menyelesaikan pekerjaan

2) Tidak menunda pekerjaan

3) Mempercepat pekerjaan

b. Tingkat absensi rendah

Tingkat absensi rendah merupakan salah satu indikasi meningkatnya semangat kerja, karena Nampak bahwa persentase absen seluruh karyawan rendah.Dimensi absensi yang rendah diukur dengan menggunakan empat indikator yaitu :

1) Cuti

2) Keterlambatan

3) Alfa

4) Sakit

c. Labour Turn Over

Tingkat karyawan keluar masuk, karyawan yang menurun merupakan .salah satu indikasi meningkatnya semangat kerja.Hal ini dapat disebabkan oleh kesenangan mereka bekerja pada perusahaan tersebut.Tingkat keluar masuk karyawan yang tinggi dapat menggangu jalannya perusahaan. Dimensi Labour turn over diukur dengan menggunakan dua indikator yaitu :

1) Setia terhadap perusahaan

2) Senang bekerja di dalam perusahaan

d. Berkurangnya kegelisahaan

Semangat kerja karyawan akan meningkat apabial mereka tidak gelisah. Kegelisahan dapat dilihat melalui bentuk keluhan, ketidaktenagaan bekerja, dan hal-hal lainnya. Dimensi berkurangnya kegelisahan diukur dengan menggunakan empat indikator yaitu :

1) Kepuasan Kerja

2) Ketenangan dalam bekerja

3) Keamanan dan kenyamanan dalam bekerja

4) Hubungan kerja yang harmonis..

\section{METODOLOGI PENELITIAN}

Metode penelitian ini menggunakan pendekatan kuantitatif. Pendekatan kuantitatif dikutip dari Sugiyono adalah metode penelitian yang berlandaskan pada filsafat positivisme, digunakan untuk meneliti pada populasi atau sampel tertentu, pengumplan data menggunakan instrumen penelitian, analisis data bersifat kuantitatif atau statistik dengan tujuan untuk menguji hipotesis yang telah ditetapkan (Sugiyono, 2013).

Metode kuantitatif digunakan bertujuan tujuan untuk menguji hipotesis yang telah ditetapkan, jenis penelitian yang menghasilkan temuan berdasarkan prosedur statistik, yang diperoleh melalui instrumen penelitian berupa angkat/kuesioner yang diberikan 
kepada sample dalam penelitian ini. pengambilan sampel dalam penelitian ini menggunakan teknik sampling jenuh dimana menggunakan semua anggota populasi dijadikan sampel. Sampel dalam penelitian ini adalah seluruh anggota KPU kota TebingTinggi sebanyak 32 orang.

\section{HASIL PENELITIAN}

\section{Pengujian Regresi Linier Berganda}

Pengujian regresi linear berganda menjelaskan besarnya peranan Variabel Kompensasi (X1), Variabel Lingkungan Kerja (X2) terhadap Variabel Semangat Kerja (Y). Analisis data dalam penelitian ini menggunakan analisis regresi linier berganda dengan menggunakan SPSS. Analisis masing-masing variabel dijelaskan dalam uraian berikut:

Tabel 4 Hasil Regresi Linier Berganda

\begin{tabular}{|c|c|c|c|c|c|c|c|}
\hline \multicolumn{8}{|c|}{ Coefficients $^{\mathbf{a}}$} \\
\hline \multirow[b]{2}{*}{ Model } & \multicolumn{2}{|c|}{$\begin{array}{c}\text { Unstandardized } \\
\text { Coefficients }\end{array}$} & \multirow{2}{*}{$\begin{array}{c}\begin{array}{c}\text { Standardized } \\
\text { Coefficients }\end{array} \\
\text { Beta }\end{array}$} & \multirow[b]{2}{*}{$\mathrm{T}$} & \multirow[b]{2}{*}{ Sig. } & \multicolumn{2}{|c|}{$\begin{array}{l}\text { Collinearity } \\
\text { Statistics }\end{array}$} \\
\hline & $\mathrm{B}$ & Std. Error & & & & Tolerance & VIF \\
\hline 1 (Constant) & 10,861 & 2,873 & & 3,780 &, 001 & & \\
\hline totalx 1 &,- 181 & , 180 &,- 154 & $-1,003$ &, 324 & ,984 & 1,016 \\
\hline totalx2 & ,472 & ,127 & ,570 & 3,707 & ,001 & ,984 & 1,016 \\
\hline
\end{tabular}

a. Dependent Variable: Semangat Kerja

Sumber : Data diolah dari SPSS (2020)

Berdasarkan hasil tersebut maka persamaan regresi linier berganda yang mempunyai formulasi : $\mathrm{Y}=\mathrm{a}+\mathrm{b}_{1} \mathrm{X}_{1}+\mathrm{b}_{2} \mathrm{X}_{2}+\varepsilon$, sehingga diperoleh persamaan : $\mathrm{Y}=$ $10,861-0,181 X_{1}+0,472 X_{2}$. Deskripsi dari persamaan regresi linear berganda di atas adalah sebagai berikut:

a) Nilai konstanta (a) sebesar 10,861 menunjukkan besarnya Variabel Semangat Kerja (Y) jika Variabel Kompensasi (X1), variable Lingkungan Kerja (X2) sama dengan nol.

b) Nilai koefisien regresi Variabel Kompensasi (X1) (b1) sebesar (-0,181) menunjukkan besarnya peranan Variabel Kompensasi (X1) terhadap Variabel Semangat Kerja (Y) dengan asumsi Variabel Lingkungan Kerja (X2) konstan. Artinya apabila faktor Variabel Kompensasi (X1) meningkat 1 satuan nilai, maka diprediksi Variabel Semangat Kerja (Y) menurun sebesar 0,181 satuan nilai dengan asumsi Variabel Lingkungan Kerja (X2) konstan.

c) Nilai koefisien regresi Variabel Lingkungan Kerja (X2) (b2) sebesar (0,472) menunjukkan besarnya peranan Variabel Lingkungan Kerja (X2) terhadap Variabel Semangat Kerja (Y) dengan asumsi Variabel Kompensasi (X1) konstan. Artinya apabila faktor Variabel Lingkungan Kerja (X2) meningkat 1 satuan nilai, maka diprediksi Variabel Semangat Kerja (Y) meningkat sebesar 0,472 satuan nilai dengan asumsi Variabel Kompensasi (X1) konstan.

\section{Koefisien Determinasi $\left(\mathbf{R}^{2}\right)$}

Koefisien determinasi digunakan untuk mengetahui presentase sumbangan pengaruh variabel independen secara simultan atau bersama-sama dalam mempengaruhi variabel dependen. Dengan kata lain nilai koefisen determinan digunakan untuk mengukur 
besarnya kontribusi variabel yang diteliti. Nilai yang dipergunakan dalam melihat koefisien determinasi dalam penelitian ini adalah pada kolom adjusted $R$ square. Hal tersebut dikarenakan nilai adjusted $R$ square tidak rentan pada penambahan variabel bebas. Nilai koefisien determinasi dapat dilihat pada Tabel 4.10 berikut :

Tabel 1 Koefisien Determinasi

\begin{tabular}{|c|c|c|c|c|c|c|c|c|c|}
\hline \multicolumn{10}{|c|}{ Model Summary ${ }^{b}$} \\
\hline \multirow[b]{2}{*}{ Model } & \multirow[b]{2}{*}{$\mathrm{R}$} & \multirow[b]{2}{*}{$\begin{array}{c}\mathrm{R} \\
\text { Square }\end{array}$} & \multirow[b]{2}{*}{$\begin{array}{l}\text { Adjusted R } \\
\text { Square }\end{array}$} & \multirow[b]{2}{*}{$\begin{array}{l}\text { Std. Error of } \\
\text { the Estimate }\end{array}$} & \multicolumn{5}{|c|}{ Change Statistics } \\
\hline & & & & & $\begin{array}{l}\text { R Square } \\
\text { Change }\end{array}$ & $\begin{array}{c}\mathrm{F} \\
\text { Change }\end{array}$ & df1 & df2 & $\begin{array}{c}\text { Sig. F } \\
\text { Change }\end{array}$ \\
\hline 1 &, $571^{\mathrm{a}}$ & ,326 & 280 & 1,13574 & 326 & 7,013 & 2 & 29 &, 003 \\
\hline \multicolumn{10}{|c|}{ Predictors: (Constant), totalx 2, totalx 1} \\
\hline Den & & 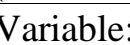 & ngat & & & & & & \\
\hline
\end{tabular}

Sumber: Data diolah dari SPSS (2020).

Berdasarkan tabel 1 dapat diketahui besarnya nilai adjusted $R$ square sebesar 0,280 atau 28,0\% Hal ini menunjukkan jika Variabel Kompensasi (X1) dan Variabel Lingkungan Kerja (X2) dapat menjelaskan Variabel Semangat Kerja (Y) sebesar 28,0\% sisanya sebesar $72 \%(100 \%-28,0 \%)$ dijelaskan oleh variabel lain di luar model penelitian ini.

\section{Uji Hipotesis}

\section{Uji t}

Uji statistik t disebut juga sebagai uji signifikasi individual. Uji ini menunjukkan seberapa jauh pengaruh variabel independen secara parsial terhadap variabel dependen. Dalam penelitian ini, uji hipotesis parsial dilakukan pada setiap variabel independen seperti pada Tabel 4.11 berikut ini:

Tabel 2 Uji Parsial (t)

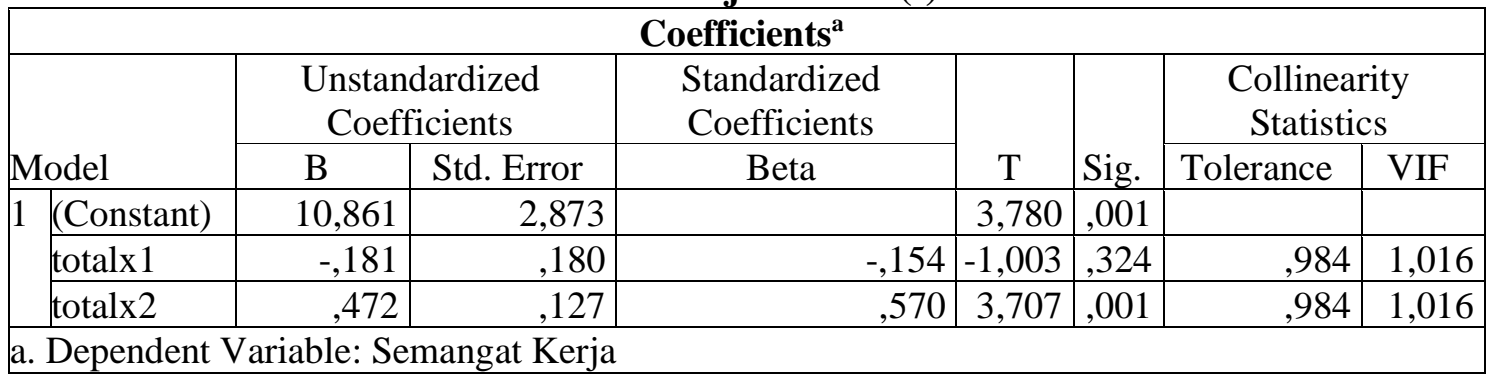

Sumber : Data diolah dari SPSS (2020)

Kriteria Pengambilan Keputusan :

a) Terima $\mathrm{H}_{0} \mathrm{Jika} \mathrm{t}_{\text {hitung }}<\mathrm{t}_{\text {tabel }}$ atau $-\mathrm{t}_{\text {hitung }}>-\mathrm{t}_{\text {tabel }}$ atau nilai Sig. $>0,05$

b) Tolak $\mathrm{H}_{0}$ Jika $t_{\text {hitung }} \geq \mathrm{t}_{\text {tabel }}$ atau $-\mathrm{t}_{\text {hitung }} \leq-\mathrm{t}_{\text {tabel }}$ atau Sig. $<0,05$

Diketahui bahwa $t_{\text {hitung }}(-1,003)>t_{\text {tabel }}(-2,042)$, demikian pula dengan nilai signifikansinya sebesar 0,324>0,05 maka dapat disimpulkan hipotesis pertama diterima, artinya Variabel Kompensasi (X1) berpengaruh negatif dan tidak signifikan terhadap Variabel Semangat Kerja. Dari tabel 2 diperoleh nilai $t_{\text {hitung }}$ sebesar 3,707 Dengan $\alpha=$ $5 \%$, $\mathrm{t}_{\text {tabel }}(5 \% ; 32-2=30)$ diperoleh nilai $\mathrm{t}_{\text {tabel }}$ sebesar 2,042 Dari uraian tersebut dapat diketahui bahwa $t_{\text {hitung }}(3,707)>t_{\text {tabel }}(2,042)$, dan nilai signifikansinya sebesar $0,001<$ 
0,05 maka dapat disimpulkan hipotesis kedua ditolak, artinya Variabel Lingkungan Kerja (X2) berpengaruh signifikan terhadap Variabel Semangat Kerja (Y).

\section{Uji F (Simultan)}

Uji ini pada dasarnya menunjukkan apakah semua variabel independen yang dimasukkan dalam model ini mempunyai pengaruh secara bersama-sama terhadap variabel dependen. Hasi uji F dapat dilihat dalam tabel 4.12 berikut:

Tabel 3 Hasil Uji Simultan (F)

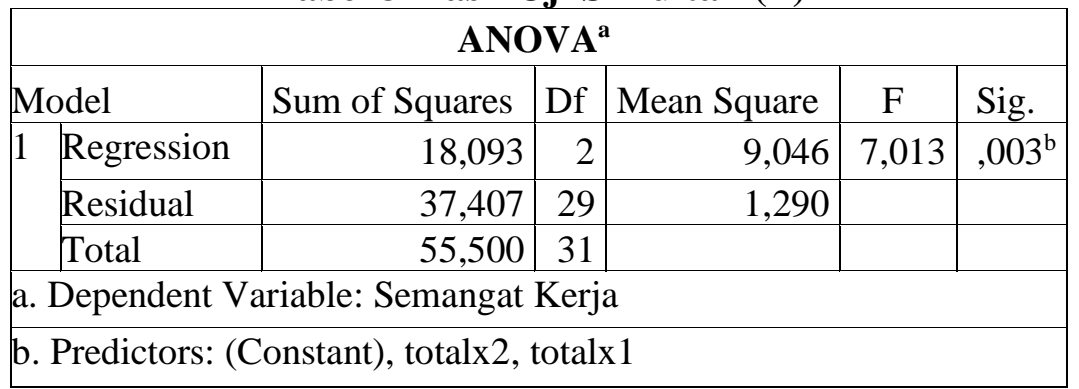

\section{Sumber : Data diolah dari SPSS (2020)}

Bentuk pengujian hipotesis berdasarkan kriteria pengambilan keputusan adalah sebagai berikut:

a) Jika nilai $\mathrm{F}_{\text {hitung }}>\mathrm{F}_{\text {tabel }}$ atau Sig. $<0,05$ maka $\mathrm{H}_{\mathrm{a}}$ diterima dan $\mathrm{H}_{0}$ ditolak.

b) Jika nilai $\mathrm{F}_{\text {hitung }}<\mathrm{F}_{\text {tabel }}$ atau Sig. $>0,05$ maka $\mathrm{H}_{\mathrm{a}}$ ditolak dan $\mathrm{H}_{0}$ diterima.

Dari tabel 3 diperoleh nilai $F_{\text {hitung }}$ sebesar 7,013 Dengan $\alpha=5 \%$, dk pembilang : 3, dk penyebut : 32-2-1 $(5 \% ; 2 ; 29)$ diperoleh nilai $F_{\text {tabel }}$ sebesar 3,29 Dari uraian tersebut dapat diketahui bahwa $F_{\text {hitung }}(7,013)>F_{\text {tabel }}(3,29)$, dan nilai signifikansi sebesar 0,003 $<0,05$ maka dapat disimpulkan hipotesis ketiga diterima, artinya Variabel Kompensasi (X1), Variabel Lingkungan Kerja (X2) berpengaruh signifikan secara bersama-sama (simultan) terhadap Variabel Semangat Kerja (Y).

\section{KESIMPULAN}

Berdasarkan analisis data dan pembahasan hasil penelitian, peneliti menarik kesimpulan bahwa Variabel Kompensasi (X1) memiliki pengaruh yang negtif dan tidak signifikan terhadap Variabel Semangat Kerja (Y). sedangkan Variabel Lingkungan Kerja (X2) berpengaruh positif dan signifikan terhadap Variabel Semangat Kerja (Y). Namun secara bersama-sama (simultan) Variabel Kompensasi (X1), dan Variabel Lingkungan Kerja (X2) berpengaruh positif signifikan dan terhadap Variabel Semangat Kerja (Y). Dan berdasarkan nilai koefisien determinasinya menunjukkan jika Variabel Kompensasi (X1) dan Variabel Lingkungan Kerja (X2) dapat menjelaskan Variabel Semangat Kerja (Y) sebesar 28,0\%.

\section{UCAPAN TERIMA KASIH}

Terimah kepada Sekolah Tinggi Ilmu Ekonomi Bina Karya Kota Tebing Tinggi, rekan dosen, pegawai KPU Kota Tebing Tinggi dan keluarga. Karya ilmiah ini saya persembahkan untuk para pembaca khususnya yang berfokus pada bidang sumber daya manusia semoga dapat memberikan masukan untuk melaksanakan penelitian selanjutnya. 


\section{DAFTAR PUSTAKA}

Alex S Nitisemito. 2011.Manajemen Personalia (Manajemen Sumber. Daya Manusia, Edisi Kelima, Cetakan Keempat Belas, Ghalia.

Hasibuan, Malayu S.P. 2009. Manajemen Sumber Daya Manusia (Edisi revisi cetakan ke tiga belas).: PT Bumi Aksara Jakarta

Hasibuan, Malayu S.P.. 2017. Manajemen Sumber Daya Manusia. Edisi Revisi.: Bumi Aksara.Jakarta.

Nuraini, T. 2013. Manajemen Sumber Daya Manusia, Yayasan Aini Syam: Pekanbaru.

Sondang P, Siagian. 2014. Manajemen Sumber Daya Manusia. Jakarta: Bumi Aksara

Sugiyono. 2013. Metode Penelitian Pendidikan Pendekatan Kuantitatif, Kualitatif, dan R\&D. Bandung: Alfabeta.

Veithzal Rivai, 2013, Manajemen Sumber Daya Manusia Untuk Perusahaan Dari Teori Ke Praktek, Rajagrafindo persada, Bandung.

Wibowo, 2016. Manajemen Kinerja, Edisi Kelima, PT.Rajagrafindo Persada-14240. Jakarta. 